$r e c e n z e$ 



\section{Bezdětný hospodář Arne Novák v zrcadle korespondence}

ŠUBRTOVÁ, Milena, ed.: Krb neporušitelného prátelství: Korespondence Arna Nováka a Marie Veselíkové. Brno: Statutární město Brno, Archiv města Brna, 2015. $320 \mathrm{~s}$.

Jméno Arna Nováka, významné osobnosti naší literární vědy a kultury, neodmyslitelně spjaté s počátky Masarykovy univerzity v Brně, se po sametové revoluci opět začalo hlasitě vyslovovat. Byla mu věnována publikace Dušana Jeřábka (Arne Novák, Brno 1997), obsahující vedle monografické studie vzpomínky současníků a výbor ukázek z Novákova odborného díla. Vyšly reedice některých jeho knih - připomeňme pro literárního historika nepostradatelné Přehledné dějiny literatury české (Brno 1995), výbor klíčových statí Česká literatura a národní tradice (Brno 1995, ed. Dušan Jeřábek a Vlastimil Válek) nebo Dějiny českého písemnictví (Praha 1994). Soupis osobního fondu Arna Nováka a jeho matky Terézy Novákové pořídil Karol Bílek (Praha 1997).

Osobnější pohled přinesly výběry z jeho korespondence, útlý svazeček Adresát: Otokar Šimek, připravený Danielou Golkovou (Liberec 2000), a dopisy manželky Jiřiny Novákové Haaszové Mému muži, Arne Novákovi (Brno 2008, ed. Olga Jeřábková). Nyní se k těmto publikacím přiřadila další, dosud nejobsáhlejší sbírka Krb neporušitelného prátelství, s podtitulem Korespondence Arna Nováka a Marie Veselíkové, kterou edičně připravila Milena Šubrtová.

Úvodní rozsáhlá studie tvoří rámec pro bližší pochopení dopisů. Editorka v ní připomíná osudy obou pisatelů, jejich osobní i pracovní peripetie, ozřejmuje také vznik a vývoj jejich vzájemného vztahu. Jádro knihy tvoří stovka dopisů. Arne Novák je autorem čtyřiceti osmi z nich - dochovaly se v rodinném archivu (nyní ve vlastnictví Mileny Šubrtové, která je příbuznou Veselíkové) a jsou veřejnosti představovány poprvé. $Z$ dopisů Marie Veselíkové, uložených v Literárním archivu PNP v Praze, editorka pořídila výběr tak, aby výsledný tvar zachovával přirozený dialogický proud. Dopisy jsou opatřeny podrobnými vysvětlivkami, knihu doplňuje ediční poznámka, jmenný heslář zmiňovaných osob, částečná 
bibliografie prací Marie Veselíkové, výběr z odborné literatury a cizojazyčná resumé (anglické a německé). Čtenářskou atraktivitu publikace zvyšuje poměrně rozsáhlá obrazová příloha, sestávající z kopií dokumentů, obrazů a fotografií, z nichž mnohé dosud nebyly publikovány. Kniha upoutá rovněž vkusnou a přehlednou grafickou úpravou. Orientaci v listáři usnadňuje barevné odlišení textů obou odesílatelů.

Marie Veselíková (1882-1948), přáteli nazývaná Máša, prozaička, publicistka a překladatelka, pocházela z kulturní rodiny s kořeny v Litomyšli. Její dědeček Jan Quido Veselík zde založil významný knihkupecký a nakladatelský dům, otec Karel Veselík, filozof, filolog a germanista, pracoval jako učitel a posléze univerzitní pedagog, matka Anna měla hudební nadání. Marie, vedená rodiči ke všem druhům umění a ke vzdělání (absolvovala Vyšší dívčí školu v Praze, jako hospitantka navštěvovala univerzitní přednášky), získává v pražských kulturních kruzích řadu přátel. Dochází do uměleckého salonu Růženy Svobodové a poznává také rodinu Terézy Novákové, s níž pojí Veselíkovy už dřívější vazby (Karel Veselík byl přítelem a bývalým spolužákem dr. Josefa Nováka). S Arnem Novákem se Máša seznamuje v r. 1901. Setkávají se na různých společenských a kulturních akcích, $v$ době odloučení si dopisují. $Z$ dlouhodobého pobytu v Paříži v r. 1902 posílá Máša do Prahy množství dopisů, v nichž s živou spontaneitou líčí kulturní zážitky. Arne Novák o své vưli zařídil otištění vybraných úryvků v Lumíru - a od té doby se stává také literárním rádcem a vlídným, leč pozorným kritikem Mášiných prací, od publicistických statí po beletristické pokusy. Zkouškou vzájemného vztahu je Mášino odmítnutí Novákova dvoření (Marie Veselíková byla v té době zamilovaná do malíře a grafika Viktora Strettiho a doufala ve společnou budoucnost). Pochopitelné odcizení se však postupně daří překonat a mezi Novákem a Veselíkovou se vyvijí silné ryze přátelské pouto, které dosvědčuje čtyřicet let trvající vzájemná korespondence. Máša se sblížila i s Novákovou manželkou Jiřinou. Sama zůstala svobodná, vztah se Strettim se rozpadl a její životní plány nenávratně změnila těžká choroba. Tuberkulóza, $\mathrm{k}$ níž se později přidalo neurologické onemocnění, Veselíkovou postupně vyčlenila z aktivního života. Po smrti rodičů se natrvalo usazuje v Litomyšli. Novákovi ji hmotně i morálně podporují, Arne jí zajištuje překladatelské příležitosti. Přátelství se uzavírá až jeho smrtí v r. 1939.

Každá korespondence je především svého druhu psychologickou studií pisatelů. Počáteční hojné a rozsáhlé dopisy představují Arna Nováka nejen jako „duši hříšně filologickou“, jak sám sebe charakterizuje, ale rovněž z poněkud méně známého úhlu pohledu: jako okouzleného mladého muže, plného oddaného 
obdivu a rytířské úcty $\mathrm{k}$ zidealizované ženě. Tón Mášiných odpovědí je hravý, místy až naivní, zároveň však odhalující velmi vnímavé a temperamentní nitro, lačně se chápající všeho, co vzněcuje cit krásou a harmonií. Přestože si adresáti v tomto období vymění množství kulturních glos a literárních hodnocení ve vzájemném názorovém souladu, čtenář nemưže necítit jakési vnitřní míjení, způsobené odlišnými očekáváními: zatímco Novákovy dopisy mají milostný nádech, Mášiny jsou podobnému smýšlení zcela cizí. O to pozoruhodnější je vzájemné vnitřní sblížení o několik let později, kdy si oba pisatelé začínají uvědomovat, že jejich přátelství je jedinečným darem. V r. 1906 tak Arne Novák může napsat: „Kdysi před půl čtvrtým rokem rozešli jsme se po krátkém klamu zabloudilých srdcí a oba jsme si slíbili, že zůstaneme přáteli navzdor všem tvrdým a prázdným konvencím, které s pýchou pokrytectví a zloby mění při rozchodech v kletbu to, co chtělo být požehnáním. Neprohřešili jsme se ani hodinu proti svému slibu a jako $V y$ jste se druhdy radovala $z$ toho, že ctím muže, jenž Vás miloval, tak já dnes děkuji Vám oddaně za pozdravy posílané té, jež jest nejkrásnějším a nejhlubším osudem mého života. Jest to snad výjimkou v dnešním světě; ale již existence přátelství, jaké jest naše, spolupracuje $\mathrm{k}$ tomu, aby výjimka proměnila se v samozřejmé pravidlo“ (s. 199). Marie Veselíková zahrnuje do svého přátelství celou Arnovu rodinu, zajímá se o všechny její členy. $S$ upřímným zármutkem a soustrastí také reaguje na tragické události (smrt Novákových sourozenců, zejména bratrů Theodora a Jaroslava, které blíže znala, smrt Arnovy matky a syna Radovana). Vyznává se rovněž z obdivu k Teréze Novákové, kterou chápe jako svou životní i literární učitelku.

Bohemistu zaujmou oboustranné glosy k postavám soudobého českého uměleckého života, at je to společný př́tel Otakar Theer, F. X. Šalda či Růžena Svobodová - přičemž druzí dva jsou zmiňováni s kultivovanou, ale nepřehlédnutelnou averzí.

Korespondence rovněž nastavuje zrcadlo době. Barvité jsou pasáže o Paříži počátku století, kde Veselíková navštěvuje různé kulturní akce, výstavy a významné osobnosti uměleckého a vědeckého světa (setkává se zde třeba s Alfonsem Muchou, Františkem Kupkou, Augustem Rodinem, Louisem Legerem či Ernestem Denisem). Emočně vypjatá a dokumentárně pozoruhodná jsou také svědectví o prvních dnech republiky. Zachycují průběh historických událostí i charakter a smýšlení pisatelů. „Včera jsem prožil návrat naší delegace ze Švýcar,“ líčí Novák 6. 11. 1918. „[...] dívky v krojích byly živými květinami a statisícohlavý zástup cítil vření radosti a pýchy v každé žilce: nejen vytrvat, žít a růst, ale i vládnout na svém! Vzpomínám denně drahých, kteří se nedočkali, 
teskním pro živé, jimž přilišná bolest, choroba neb stáří nedovolují se radovat s námi, ale vím, přes leckterou starost a úzkost, že celý náš život bude zmnohonásoben“ (s. 257). Dvacátá léta pak přinášejí už obraz méně rozjásaný: Novákových dopisů ubývá, omlouvá se nedostatkem času při plnění nelehkých úkolů spjatých s univerzitní činností: „Děkanský úřad sám sebou přináší spoustu konceptní i kancelářské práce, i když jest rok nejpokojnější. Letošek však není: nejprve jsme se musili hájiti proti ušlechtilému utrhačství prof. Krejčího, [...] nyní nám zase nastal zápas s ministerstvem vyučování, které se doposud nevzdalo absurdního plánu přeložiti nás do Bratislavy [...]“ (s. 267). A poslední otištěný list Arna Nováka, ze záři 1936, zaznívá smutkem a skepsí, když v souvislosti s připravovanými Přehlednými dějinami píše: „[...] neshledávám v mladé generaci ve svém oboru mnoho osobností, jež bych mohl a chtěl označiti jako své duševní dědice. V několikerém smyslu: bezdětný hospodář!“ (s. 284).

Precizně editovaný Krb neporušitelného prátelství je publikací, která počítá s odborníky - literárními vědci - i s širším čtenářským okruhem. Umožňuje hlouběji nahlédnout do života a díla člověka významného nejen stopou, již zanechal v našich kulturních dějinách, ale velkého i svou skromností, pracovitostí, neúplatným charakterem a citem pro krásu. Kniha tak doplňuje dosavadní literárněvědná bádání o něm a záslužně připomíná osobnost zajisté známou, ale přece snad ne tak často připomínanou a do té míry oceňovanou, jak by si zasloužila.

Ester Nováková 